\title{
Explaining Yudhoyono's Decision To Develop A Strategic Partnership With China
}

\author{
Petrus K. Farneubun \\ Department of International Relations and Organization, University of Groningen \\ Groningen, the Netherlands \\ p.k.farneubun@rug.nl \\ Department of International Relations \\ Cenderawasih University \\ Jayapura, Indonesia \\ petrus.farneubun@unicen.ac.id
}

\begin{abstract}
Several studies by Indonesian and foreign scholars have addressed Yudhoyono's leadership and the roles of bureaucracies in Indonesia's foreign policy. However, their analyses tend to be rather general and highly emphasise the personal characteristics of the president and the role of the minister of foreign affairs. Although they are important, this paper proposes that other bureaucracies have also come to play new important roles in Indonesian foreign policymaking. To demonstrate their pivotal position, this paper highlights Indonesia's foreign policy towards China at the time of president Yudhoyono with specific reference to the "strategic partnership agreement" signed in 2005 , later upgraded to a "comprehensive strategic agreement" in 2013. This paper makes two overarching claims. First, the relation with China is driven by Yudhoyono's vision that compels him to promote "development through comprehensive changes. Second, the relation is shaped by his bureaucracies generated through Yudhoyono's weak leadership and the implication of domestic political change.
\end{abstract}

Keywords- Strategic Partnership, Bureaucracies, Weak Leadership, Domestic Politics, Foreign Policy

\section{INTRODUCTION}

The collapse of authoritarian rule substantially shifts Indonesia's foreign policy to greater engagement and integration with global and regional major players, notably China. Indonesia's domestic politics and the strategic roles of China for Indonesia's development have led to growing interests in building a closer relation with China. China is no longer viewed as a threat but as a strategic partner. Although all postauthoritarian governments have initiated a stronger cooperation with China, it is fair to say that the relation reached its highest form under Yudhoyono's administration marked by the signing of two important agreements: the strategic partnership agreement in 2005, later upgraded to comprehensive strategic agreement in 2013.Yudhoyono becomes Indonesia's first president to sign the agreements and makes Indonesia the first ASEAN country to have reached the status of comprehensive partnership with China. The strategic partnership agreement was echoed as, "the most significant achievement in Indonesia's foreign policy in 2005" and signified "a major turn-around in Sino-Indonesia relations" [1]. President Yudhoyono himself referred to the agreement as a historic milestone whilst President Hu Jintao called it the beginning of entering into a new era in bilateral relations [2]. This paper seeks to explain the principal factors that drove Yudhoyono to sign the agreements. While one might argue that the concern of national interest notably economic development can explain the decision, I contend that this argument fails to explain why other presidents who also emphasize economic cooperation with China did not take decision as Yudhoyono did. Therefore, this paper intends to demonstrate that Yudhoyono's vision and the influence of bureaucracies play decisive roles in his decision. While, the involvement of bureaucracies derives from their bureaucratic roles and their expertise, it is also generated by Yudhoyono's weak leadership and domestic political change. To establish a link between Yudhoyono's vision and his foreign policy decision, this article investigates his policies, initiatives, and political statements that reflect his vision of sustainable economic growth. This research builds on the perception that if there is a close connection between his governmental and political behavior reflected in his policies and statements and his foreign policy making, it suggests that Yudhoyono's decision to sign the strategic partnership with China is likely driven by his vision. Meanwhile, to assess the influence and involvement of bureaucracies, this article looks at policy statements made by key bureaucracies who promote and favor the Indonesia-China strategic cooperation, Yudhoyono policy and political behavior; and constitutional amendments and laws enacted which grant bureaucracies a greater access in policy-making process. If these indicators exist, it seems reasonable to assume that the bureaucracies are likely to play roles in the policy making. An absence of these indicators, therefore, indicates a lack of bureaucratic influence. 


\section{ANALYSIS}

\section{A. Making Comprehensive Changes for Sustainable Development}

Yudhoyono built his vision based on four pillars: prosperity, peace, justice and democracy. ${ }^{1}$ Although the four pillars are strongly linked and mutually reinforcing, this research primarily focuses on prosperity because Yudhoyono highly emphasized it in his election campaigns and continued to do this through two terms in office (2004-2009; 20092014). Also, the prosperity pillar closely relates to economic cooperation in which is the core of Indonesia-China cooperation. His vision drove him to undertake some "comprehensive changes." Numerous indications can lead us to this conclusion.

Yudhoyono repeatedly promised of making changes during his presidential campaigns, in numerous speeches and remarks on official occasions. In a conference held before the 2004 presidential election, Yudhoyono declared his vision for Indonesia 2004-2009. He said,

What we need is a change for the better. A better government. A better governance. A better society. A better political culture. A better environment. A better future. And this is why I decided to run for the President of Indonesia because I truly believe that Indonesia can do better, can be better, and deserves better [3].

Although this declaration demonstrates a comprehensive list of changes, Yudhoyono was very specific that the "change has a target and a plan and that change has relevance to the lives of the people" [4]. According to Yudhoyono, "Change...is the essence of adaptability, the hallmark of progress, and...the necessary measure of survival" [5]. Yudhoyono was inspired by China's impressive economic performance which took place since the 1970s following major changes in its policy. Yudhoyono acknowledged that China is the important player today because in the 1970s China changed course, adopted Four Modernizations, opened up to the outside world, and embraced market principles [6]. Therefore, he frequently called for closer ties with China [7] and encouraged Indonesia to "learn from China, not only regarding trade and investment but also in the use of technology" [8].

Building a strategic partnership with other countries to boost economic development and present Indonesia as a great country globally is informed by choice of foreign policy direction. It was the reason that Yudhoyono changed the country's foreign policy orientation from inward looking to outward looking. With his foreign policy "all-direction

${ }^{1}$ These pillars can be found in Yudhoyono's speeches, remarks and policy documents. For example, in his early speech delivered in a conference on "Presidential Election in Indonesia, on May 26, 2004, he explained these four pillars respectively in which prosperity came first. foreign policy and navigating in a turbulent ocean" under the slogan "a thousand friends zero enemies-later changed to million friends zero enemies," Yudhoyono proposed the idea of "dynamic equilibrium" which according to Anwar, is to "involve all the major relevant powers within a more cooperative framework as a basis for the development of an inclusive regional architecture" [9].

Likewise, to attract investments and strong partnerships, Yudhoyono promoted an open-door economic policy focusing on growth and development through promoting exports/trade, investments and modernizing infrastructure. He targeted $6.5 \%$ annual economic growth. His ambition led him to introduce "Triple Strategy" consisting of promoting growth through exports and investment; promoting employment by stimulating the real sector; and reducing poverty by promoting agriculture and rural development. The triple track strategy is in essence progrowth, pro-jobs, pro-poor [10] [11] [12]. The implementation of these two policies has led to the increase in bilateral and multilateral agreements and newly signed MoUs between Indonesia and China and business groups. His policy is likely to be influenced by China's foreign policy of "Good Neighbour" and Open-Door Policy introduced in 1978/79 that successfully made China one of the world largest economies.

However, reaching a stable and sustainable economic growth requires an adequate infrastructure. Yudhoyono was not satisfied with the country's infrastructure and called for public-private partnership [13]. According to Yudhoyono, "Infrastructure development is a real key" if Indonesia wants to achieve an impressive rate of economic development [14]. To promote Indonesia's infrastructure, Yudhoyono undertook a number of initiatives by signing presidential regulation No. 67/2005 on scheme for infrastructure development through public-private partnership, making infrastructure one of the five key priorities in Indonesia's Medium-Term Development Plan 2004-2009; launching the Master Plan for the acceleration and expansion of Indonesia's Economic Development (MP3EI) 2011-2025 through increasing infrastructure development and improving investment climate; hosting two consecutive infrastructure summits on 17 January 2005 and in November 2006 which attracted hundred participants and foreign investors. Inadequate supply of infrastructure, in fact, ranks the first as the most problematic factors for doing business in Indonesia, according to Global Competitive Report 2006-2007 published by World Economic Forum [15].

China is the major partner for the infrastructure initiatives. Most of the Indonesia's current mega projects are financed by Chinese investors and businesses. According to the Jakarta Post, "China has...become a major financier to mega projects in Indonesia; the role played by the World Bank, ADB, Europe, Japan and the United States in the past" [16]. In fact, following the signing of strategic partnership, China agreed to add $\$ 200 \mathrm{~m}$ in loans to finance major infrastructure projects in the country [17], and both leaders 
expect to expand bilateral trade to reach US\$20 billion over the next three years, from the current $\$ 14$ billion [18]. Also, following the bilateral signing meetings, official visits to China by the president and ministers were conducted more regularly and more newly MoUs were signed between the two countries and business and private sectors.

\section{B. The Involvement of Bureaucracies}

Yudhoyono was not a predominant leader because bureaucratic dominance tended to prevail in Yudhoyono's policymaking. Their influence can be indicated by their policy advocacy towards a strategic cooperation with China, their active involvement in bilateral meetings with Chinese officials and business group.

On the one hand, the roles of bureaucracies related to the democratically bureaucratic arrangement in which Yudhoyono before making a decision, needed to engage with bureaucratic actors. One the other hand, his lack of foreign policy expertise and understanding of foreign trade and investment compelled him to seek policy recommendation and advice from bureaucracies notably his ministries.

The bureaucracy here refers to "any large-scale organization of appointed officials whose primary function is to implement the policies of the decision makers" [19]. Similarly, Halperin et al. define bureaucracy as "civilian career officials and political appointees, as well as to military officers" [20]. This article expands the definition to indicate that the roles and functions of bureaucracies are not limited to implementing decisions but also formulating policy, making decisions and giving advice.

Their supports and preferences related to their positions in the ministries and can be indicated by their repeatedly favorable statements on the cooperation. It confirms Allison's (1969) aphorism "where you stand depends on where you sit." It is interesting to find that key governmental bureaucracies which were responsible for the conduct of Indonesia's foreign policy, economic affairs including trade and investment favored strong economic cooperation with China

Minister of Foreign Affairs, for example, was responsible for setting up foreign policy priorities. However, he advocated that the nation's foreign policy should shift focus in 2013 to promote economic development, improve bilateral cooperation with strategic partners, expand nontraditional markets and promote sustainable and balanced economic growth [21]. Earlier, in his annual press statement delivered 7 January 2011, he also stressed that Indonesia will continue to develop strategic and comprehensive partnerships with Russia, China, India, Japan and Republic of Korea [22] and argued that Indonesia-China relation is crucially important to peace, development and stability in the region [23].

In addition, Indonesian ministers of trade have been the leading actors in promoting stronger cooperation between Indonesia and China. Yudhoyono's role in policy making relating to economic reform was insufficient. Most of the policies including their technical details and direction were drafted and shaped by ministers and their senior officials, particularly the Minister of Trade [24].

Although undergoing three cabinet reshuffles from Mari Elka Pangestu, Gita Wirjawan to Muhammad Lutfi, these ministers continued to make the strategic partnership a key policy agenda. Pangestu, for example, with Chinese Minister of Trade established a forum namely the Joint Commission on Economic, Trade, and Technical Cooperation with the aim to enhance the bilateral relations in the economic, trade and technical areas and to implement the strategic partnership commitment, and through this commission, the Government of China agreed to finance some Indonesian infrastructure projects [25]. Pangestu was also keen on promoting strategic partnership to a higher level. In her speech at Business Luncheon on the sidelines of $10^{\text {th }}$ JMC Indonesia-PRC on April $2^{\text {nd }}, 2010$, Pangestu outlined her plan to move the strategic partnership to the higher level. She said, "To take the strategic partnership to a higher level...we need a clear action plan to realize new targets. We will be setting new quantitative targets for bilateral trade and prioritization of investment and economic cooperation [26].

Wirjawan also shared the same view. He maintained "Infrastructure development is an important element to achieve economic growth, and this investment cooperation is in line with MP3EI program which is now being promoted by the government" [27]. For that reason, Wirjawan urged the strategies ties between Indonesia-China upgraded to a higher level [28]. Both Pangestu and Wirjawan sought to convince the president and Indonesian people that having a strategic partnership and comprehensive strategic partnership with China would boost Indonesia's economy and this would mark the success of Yudhoyono's administration.

Strong support for the closer partnership with China also come from the coordinating ministers for economic affairs who were actively involved in promoting strong economic cooperation with China. Similar to the Minister of Trade, although undergoing five reshuffles: Aburizal Bakrie (20042005), Boediono (2005-08), Sri Mulyani (2008-2009), Hatta Rajasa (2009-14), and Chairul Tanjung (2014), they played an essential role in shaping Indonesia's policy towards China. Bakrie, for example, called Chinese business to invest in Indonesia's various development sectors including infrastructure development project which was offered by Indonesia after the signing of the strategic partnership [29] and expect an increase in Indonesia-China bilateral trade [30] [31]; Sri Mulyani sought to strengthen strategic partnership and promoted the acceleration to comprehensive strategic partnership from strategic partnership [32]; Rajasa also sought to push Indonesia-China relations to a new level, advance the implementation of relevant agreements and raise the level of cooperation [33].

\section{Yudhoyono's weak leadership}

As explained earlier, Yudhoyono was not a predominant leader because his key bureaucracies influence his decision to forge a strategic partnership with China.

Although their involvement reflects a continuity of bureaucratic roles and arrangement, such roles do not stem 
exclusively from their positions and the roles in the government office; rather it is also generated by Yudhoyono's weak leadership. His weak leadership compelled him to seek support from his bureaucracies and relies on the inputs and insights from his ministers. Cabinet meetings were held regularly where Yudhoyono received advice and inputs from his ministries on policy issues [34].

A number of prominent scholars have also identified him as a hesitant and insecure decision maker [35] [36] [37] [38] [39]. According to Soesatyo, Yudhoyono is a president who always considers many things before taking a decision, thinks carefully before taking the decision and involves many people in the process of decision making [40]. Fealy describes Yudhoyono as an indecisive, dithering, hesitant, insecure, waverer or doubtridden person [41]. By getting input and recommendations from his bureaucracies, Yudhoyono tried to avoid making unpopular policy and avoid being blamed for any decisions he made.

A close examination of his 807-page best-selling book "Selalu Ada Pilihan (There is always a choice)" reveals his leadership behavior. He involved many people in his policymaking because he prevented confrontations and conflicts with his ministers. Also, by issuing 12 rules of the game and code of conducts, he sought to maintain a good relationship with and among his cabinets and expected his ministries to increase their performance.

Yudhoyono understood that conflicts would weaken his administration and is not healthy for domestic and foreign investors. He was more interested in creating stability rather than chaos. Stability is important for economic development. He said, "...our economy will not grow if our country is not stable. Without social, political, and security stability, investments and business will be paralyzed and inoperative" [42]. On his address during Foreign Policy breakfast, he made it clear that if Indonesia has a conflict of interests with other countries, our choice will be "diplomacy first" [43].

In an interview with Aspinal and Mietzner in December 2014, Yudhoyono openly admitted, "I love stability, I love order" [44]. As also pointed out by him in his book, "In crucial things, unity" [45]. Yudhoyono's political character of preferring stability, order and government continuity was reflected by his decision to name his cabinet "united cabinet." This choice suggests a rational and strategic choice to unite all divergent and conflicting interests among key players and unite professionals, technocrats, former military officers and politicians together to sit in his cabinet.

\section{Impacts of Domestic politics change}

Domestic politics change also leads to a greater involvement of bureaucracies in policy making. Four constitutional amendments and the introduction of new laws not only contribute the policy and bureaucratic reforms but also provide greater access for bureaucrats to participate in political process including policy decision-making process. Scholars agree that democratization has led to a greater involvement of state officials and parliaments on the conduct of Indonesia's foreign policy [46] [47] [48] [49] [50] [51] [52] [53] [54]
The introduction of law No.37/1999 on Foreign Relations, for example, provided a legal basis for the conduct and implementation of foreign policy which regulated the need of coordination and consultation between government agencies and between units within the foreign ministry. It also redefined Indonesia's foreign relations to all activities covering regional and international aspects conducted by state and nonstate actors including business groups. Similarly, Law 24/2000 on International Agreements required an extensive consultation and coordination process between the executive, the legislature and other relevant agencies [55] [56]

In addition, the change of domestic politics greatly affects the distribution of shared responsibilities across bureaucracies. A central and strategic issue no longer becomes exclusive domain of a particular bureaucracy or institution but shared across bureaucracies and government agencies. In this sense, the President needs to make sure that his policy is implemented and executed by his ministries. Therefore, presidential always issued some regulations that grant specific power for bureaucracies to exercise their bureaucratic roles to implement the policies and promote the investments and trade sectors. Presidential decision No. 3/2006 on National Team to Increase Exports and Investment grants special power to several key ministers including coordinating ministers for politics, law and security, ministry of trade, ministry of foreign affairs. This team is headed by Coordinating Minister for Economic Affairs with the tasks, among others, are to formulate general guidelines and take necessary measures on increasing exports and investments. Also, presidential instruction No. 3/2006 on Policy Package for Improving Investment Climate grant several key ministers to take necessary measures by their tasks, functions and powers to create a friendly-environment for investments. There are also a number of similar regulations, presidential decisions and instructions which legitimate powers and authority to his ministers and relevant agencies to promote trade, investments and infrastructures.

\section{CONCLUSION}

This article has demonstrated that Yudhoyono's policy to seek a closer relation with China under the strategic partnership agreement constitutes an ambitious plan to promote Indonesia's sustainable economic growth and infrastructure. The policy reflects the very nature of his vision and belief on the "development through comprehensive changes" by reforming foreign policy, introducing open-door policy and modernizing infrastructure. Although the president is the key actor, the article shows that his bureaucracies, his weak leadership and domestic political change have also contributed to his policy-making towards China. Meanwhile, his decision to build a strong cooperation with China derives from his special recognition and perception on the importance of China's role for Indonesia's economic development. 


\section{REFERENCES}

[1] Lanti, Irman, G. "Indonesia: accomplishments amidst challenges.” Southeast Asian Affairs, 2006:103, pp. 91-110

[2] Minister of Trade, Republic of Indonesia Mari Elka Pangestu's address on the seminar Sino-Indonesian relations: Substantiating the Strategic Partnership Between Indonesia and China, 9 May 2006

[3] Yudhoyono, Susilo Bambang. Presidential Election in Indonesia. 2004-2009 Vision for Change. Speech delivered at Shangri-La Hotel, Singapore on May, 26, 2004

[4] Yudhoyono, Susilo Bambang. Indonesia: The Challenge of Change. The Singapore Lecture, 16 February 2005.

[5] ibid

[6] ibid

[7] The Jakarta Post. Susilo wants closer relations with China. 28 July 2005

[8] The Jakarta Post. Indonesia should learn from China, President says. Jul 30, 2005

[9] Anwar, Dewi Fortuna. "Indonesia's foreign relations: policy shaped by the ideal of "dynamic equilibrium." East Asian Forum, $\quad 4 \quad$ February 2014. http://www.eastasiaforum.org/2014/02/04/indonesias-foreignrelations-policy-shaped-by-the-ideal-of-dynamic-equilibrium/ (Accessed July 7, 2017)

[10] Yudhoyono, Susilo Bambang, Remarks on Mengenali Masalah, Menetapkan Agenda dan Arah (Understanding the Problems, Setting Agenda and Directions), 17 November 2004. The speech is available at http://kepustakaanpresiden.pnri.go.id/uploaded_files/pdf/speech/normal/susilo19. pdf (Accessed July 10, 2017)

[11] Yudhoyono, Susilo Bambang. Indonesia: The Challenge of Change. The Singapore Lecture, 16 February 2005

[12] Yudhoyono, Susilo Bambang. Democracy is Good For Business. Speech delivered at the opening of Forbes Global CEO Conference in Singapore, 4 September 2006. Indonesia on the Move. Selected Speeches and Articles by the President of the Republic of Indonesia. Jakarta: PT Bhuana Ilmu Populer

[13] Yudhoyono, Susilo Mambang. "Selalu Ada Pilihan" [There is Always a Choice). Jakarta: Kompas Gramedia, 2014:82

[14] Yudhoyono, Susilo Bambang. Presidential Election in Indonesia. 2004-2009 Vision for Change. Speech delivered at Shangri-La Hotel, Singapore on May, 26, 2004

[15] World Economic Forum.The Global Competitiveness Report 2006-2007.

http://www3.weforum.org/docs/WEF_GlobalCompetitiveness Report_2006-07.pdf (8 July 8, 2017).

[16] The Jakarta Post. 60 years Indonesia-China Relations. 13 April 2010

[17] The Jakarta Post. China agrees to add $\$ 200 \mathrm{~m}$ in loans: Jusuf, 29 June 2005

[18] The Jakarta Post. RI-China seal multibillion deal to strengthen trade. 26 April 2005

[19] Naidu, S.P. (2005). Public Administration: Concepts and Theories. New Delhi: New Age International Publishers, p.80

[20] Halperin, Morton M; Clapp, Priscilla A and Kanter, Arnold. (2006). Bureaucratic Politics and Foreign Policy (2nd ed). Washington: Brookings Institution Press, p.4

[21] The Jakarta Post. Marty calls for focus on economy, regional ties. 5 January 2013

[22] Natalegawa, Marty. Speech of the Minister of Foreign Affairs, 2011 Annual Press Statement. Available from http://indonesia.gr/speech-of-the-minister-of-foreignaffairsannual-press-statement-of-the-foreign-minister-of-therepublic-of-indonesia-dr-r-m-marty-m-natalegawa/ (Accessed August 10, 2017)
[23] Ministry of Foreign Affairs of the PRC. Foreign Minister Wang Yi Meets with Foreign Minister of Marty Natalegawa of Indonesia.

http://www.fmprc.gov.cn/mfa_eng/wjb_663304/zzjg_663340/y zs_663350/gjlb_663354/2716_663436/2718_663440/t1072361 .shtml (Accessed August 18, 2017)

[24] Sherlock, Stephen. A balancing act: relations between state institutions under Yudhoyono. In Aspinal, Edward; Mietzner, Marcus; and Tomsa, Dirk (eds). "The Yudhoyono Presidency: Indonesia's Decade of Stability and Stagnation." Singapore: Institute of Southeast Asian Studies, 2015:108.

[25] Minister of Trade, Republic of Indonesia Mari Elka Pangestu's Address on the Seminar Sino-Indonesian Relations: Substantiating the Strategic Partnership Between Indonesia and China, 9 May 2006

[26] Minister of Trade. Speech Minister of Trade of the Republic of Indonesia At Business Luncheon on the sidelines of 10th JCM Indonesia-PRC April 2nd, 2010. The speech is available at http://www.kemendag.go.id/files/pdf/2010/04/02/speech-ofthe-minister-of-trade-at-business-luncheon-on-the-sidelines-of10th-jc-en1-1353762609.pdf (Accessed August 5, 2017)

[27] Minister of Trade Press Release 2012. Indonesia-PRC Collaboration Worth USD 17.6 Bilion. http://www.kemendag.go.id/files/pdf/2012/03/24/beijingindonesia-rrt-sepakati-kerja-sama-senilai-usd-176-miliar-en11353753974.pdf (Accessed August 3, 2017)

[28] Minister of Trade Press Release 2012. Indonesia-PRC Collaboration Worth USD 17.6 Bilion. http://www.kemendag.go.id/files/pdf/2012/03/24/beijingindonesia-rrt-sepakati-kerja-sama-senilai-usd-176-miliar-en11353753974.pdf (Accessed August 3, 2017)

[29] The Jakarta Post. China agrees to add $\$ 200 \mathrm{~m}$ in loans: Jusuf, $29 / 06 / 2005$

[30] The Jakarta Post. Business 'Key to AA Partnership, $22 / 04 / 2005$

[31] The Jakarta Post. SBY to wrap up deals in China trip, $27 / 07 / 2005$

[32] Xinhua News Agency. Indonesia, China vow to boost strategic partnership. http://www.china.org.cn/international/200903/23/content_17489055.htm (Accessed July 23, 2009)

[33] Minstry of Foreign Affairs of the People's Republic of China. Vice Premier Hui Liangyu Holds Talks with Indonesian Coordinating Minister for Economy Hatta Rajasa http://www.fmprc.gov.cn/mfa_eng/wjb_663304/zzjg_663340/y Zs_663350/gjlb_663354/2716_663436/2718_663440/t921934.s html (Accessed July 30, 2017).

[34] Fealy, Greg. The politics of Yudhoyono: majoritarian democracy, insecurity and vanity. In Aspinal, Edward; Mietzner, Marcus; and Tomsa, Dirk (eds). "The Yudhoyono Presidency: Indonesia's Decade of Stability and Stagnation." Singapore: Institute of Southeast Asian Studies, 2015:46

[35] Lesmana, Tjipta. "Dari Soekarno sampai SBY: intrik \& lobi politik para penguasa" [ from Soekarno until SBY: Strategies and Political Lobbies of the Power]. Jakarta: Gramedia Pustaka Utama, 2009:

[36] Soesatyo, Bambang. "Presiden Dalam Pusaran Politik Sengkuni" [president within the circle of politics] Jakarta: RMBooks, 2013

[37] Aspinal, Edward, Mietzner, Marcus, and Tomsa, Dirk. The moderating president: Yudhoyono's decade in power. In Aspinal, Edward; Mietzner, Marcus; and Tomsa, Dirk (eds). "The Yudhoyono Presidency: Indonesia's Decade of Stability and Stagnation." Singapore: Institute of Southeast Asian Studies, 2015

[38] Fealy, Greg. The politics of Yudhoyono: majoritarian democracy, insecurity and vanity. In Aspinal, Edward; Mietzner, Marcus; and Tomsa, Dirk (eds). "The Yudhoyono Presidency: Indonesia's Decade of Stability and Stagnation." Singapore: Institute of Southeast Asian Studies, 2015 
[39] McBeth, John. “The Loner: President Yudhoyono's decade of trial and indecision." Singapore: Sraits Times Press, 2016.

[40] Soesatyo, Bambang. "Presiden Dalam Pusaran Politik Sengkuni" [president within the circle of politics] Jakarta: RMBooks, 2013:ix

[41] Fealy, Greg. The politics of Yudhoyono: majoritarian democracy, insecurity and vanity. In Aspinal, Edward; Mietzner, Marcus; and Tomsa, Dirk (eds). "The Yudhoyono Presidency: Indonesia's Decade of Stability and Stagnation." Singapore: Institute of Southeast Asian Studies, 2015

[42] Yudhoyono, Susilo Mambang. "Selalu Ada Pilihan" [There is Always a Choice). Jakarta: Kompas Gramedia, 2014:39

[43] Yudhoyono, Susilo Bambang. President's address during Foreign Policy Breakfast, 19 August 2008). The full speech is available http://www.setneg.go.id/index.php?option=com content\&task =view\&id=2571\&Itemid=26 (August 10, 2017)

[44] Aspinal, Edward, Mietzner, Marcus, and Tomsa, Dirk. The moderating president: Yudhoyono's decade in power. In Aspinal, Edward; Mietzner, Marcus; and Tomsa, Dirk (eds). "The Yudhoyono Presidency: Indonesia's Decade of Stability and Stagnation." Singapore: Institute of Southeast Asian Studies, 2015:7

[45] Yudhoyono, Susilo Mambang. "Selalu Ada Pilihan" [There is Always a Choice). Jakarta: Kompas Gramedia, 2014:38

[46] Dosch, Jörn, "The impact of democratization on the making of foreign policy in Indonesia, Thailand and the Philippines." Journal of Current Southeast Asian Affairs, 2006, vol. 25, issue 5, pp. $42-70$

[47] Rüland, Jürgen. "Deepening ASEAN cooperation through democratization? the Indonesian legislature and foreign policymaking," International Relations of the Asia-Pacific Vol 9 (2009), no. 3, pp: 373-402.

[48] Anwar, Dewi Fortuna. "The impact of domestic and Asian regional changes on Indonesian foreign policy." Southeast Asian Affairs. No. 1(2010), pp. 126-141

[49] Gindarsah, Iis, "Democracy and foreign policy in Indonesia: a case study of the Iranian nuclear issue," 2007-2008. Contemporary Southeast Asia. Vol. 34, No. 3 (December 2012), pp. 416-437

[50] Laksmana, Evan A. "Indonesia's rising regional and global profile: does size really matter?" Contemporary Southeast Asia, Vol. 33, No. 2 (August 2011), pp. 157-182

[51] Nabs-Keller,Greta (a), "Reforming Indonesia's Foreign Ministry: ideas, organization, and leadership," Contemporary Southeast Asia, 35, no. 1 (2013): pp. 56-32.

[52] Nabbs-Keller Gret (b), "The impact of democratization on Indonesia's foreign policy." Unpublished $\mathrm{PhD}$ Dissertation, Griffith University, October 2013
[53] Mietzner, Marcus. "Military Politics, Islam, and the State in Indonesia: From Turbulent Transition to Democratic Consolidation." Singapore: Institute of Southeast Asian Studies, 2009.

[54] Wirajuda, Muhammad Hadianto, "The impact of democratisation on Indonesia's foreign policy: regional cooperation, promotion of political values, and conflict management." Unpublished Thesis London School of Economic and Political Science, 2014.

[55] Nabs-Keller,Greta (a), "Reforming Indonesia's Foreign Ministry:ideas, organization, and leadership," Contemporary Southeast Asia, 35, no. 1 (2013): pp. 56-32.

[56] Nabbs-Keller Gret (b), "The impact of democratization on Indonesia's foreign policy." Unpublished PhD Dissertation, Griffith University, October 2013. 